Sir: To Your Majesty's Most Gracious Person. Your most loving and loyal subject. Prince Carlos.'

(M. Ferrer et al., Historia tradicionalismo español, vol. II, p. 274.)

137

Letter of Fernando VII to his brother Carlos, condemning him to exile

\title{
I 833
}

'Madrid, 6th May 1833. - My dearest brother, my most beloved Carlos... I have ever been persuaded of the love you bear me. I believe that you are persuaded also of the affection I have for you, but I am a father and a king and I must look to my rights, to those of my daughters and to those of my crown. - It is not my wish to make you go against the dictates of your conscience nor am I able to dissuade you from laying claims to rights, which, founded on the decisions of men, you believe only God can revoke. But the brotherly love I have always borne you induces me to spare you the vexations which a country where your hypothetical claims are not recognised would offer, while the duty of a king forces me to exile from the realm a Prince whose claims could be a focal point for the restlessness of malcontents.

Being forbidden to return to Spain for important reasons of state, by the law of the realm which expressly forbids it, and in the interests of your own well-being which I desire as fervently as that of my people, I hereby grant you licence to travel forthwith to the Pontifical States letting me know where exactly you are going and where you finally decide to set up house. One of my warships will put in at Lisbon harbour in the near future to take you ... Farewell, my beloved Carlos: please believe I have always loved you, I still do and always shall. Your most affectionate and constant brother, Fernando.'

(Lafuente, Historia general de España ..., vol. V, p. 597.) 